S. Oberemok ${ }^{1}$, Yu. Dolgiy ${ }^{2}$, S. Khmelevskii ${ }^{2}$, S. Rud ${ }^{3}$

${ }^{1}$ Kirovohrad Flight Academy National Aviation University, Kropyvnytskyi, Ukraine

${ }^{2}$ Ivan Kozhedub Kharkiv National Air Force University, Kharkiv, Ukraine

${ }^{3}$ Air Command "Zakhid", Lviv, Ukraine

\title{
IMPACT ASSESSMENT OF DATA SET PROCESSING REFUSAL ON TIME CHARACTERISTIC OF DATA PROCESSING BY AIR TRAFFIC IN ACS NETWORK
}

\begin{abstract}
During transfer of information in automated control system network by air traffic is a high probability of durable spike load. The purpose is to analyse influence of possible switching node faults on the basis of data transfer process time characteristic in error-control mode by receiver. It is shown that the increase of discard probability on interconnection node of communication reduce to increasing nondimensional average time of message delivery for wide parameter range and can reduce to complete cessation of information exchange. A probabilistic and temporal characteristic of supply control method of data set transfer in data-exchange network requires consideration of interconnection switching node. There is a necessity to consider both the existence of several data flows from other sources and possibility of fault occurrence in operation on each of switching nodes.
\end{abstract}

Keywords : data transfer; switching node; probabilistic and temporal characteristics; air traffic ACS; data set, time-out; correlation; fixing errors.

\section{Introduction}

Research objective. Research of probabilistic and temporal characteristic of supply control method of data set transfer in data-exchange network (DEN) requires consideration of interconnection switching node (SN). In addition to the above, generally should be considered both the existence of several data flows from other sources and possibility of fault occurrence in operation on each of SN.

Analysis of the well-known publications. The [1] shows the possibility of data set loss on $\mathrm{SN}$ under conditions of spike load.

The [2] shows a model which helps to research main probabilistic and temporal characteristics of data transfer process in air traffic ACS net for fixing errors mode by receiver during data transfer through interconnection switching node without denial of service.

The [3] developed a model which helps to research main probabilistic and temporal characteristics of data transfer process in air traffic ACS net for fixing errors mode by receiver with the additional information flow from another sources and switching node problems.

Purpose of the article. Analysis of possible switching node influence in air traffic ACS net on the main probabilistic and temporal characteristics of data transfer process in the fixing errors mode by receiver.

\section{Main material}

Message passing through interconnection SN with checking data sets by receiver and reconstruction of lost or distorted data sets (with encountered error) with the help of retries is considered.

The source gives a message length in $M$ bit which divides into $m$ bit data sets with information part. The total number of data sets generated from the message is $M / m$. Each data set is accompanied by $k_{c л}$ service bit and $r$ check bit. The total length of the generated data set is

$$
n=m+k_{b}+r
$$

Assume that each of the switching nodes, number of which is denoted by $\beta$, in the case of an overflow of input buffers possible denial of service, i.e. data set loss probability $P_{6 m p}^{B K}$.

The duration of the retransmission time-out is proportional to the data set delivery time:

$$
T_{T A}=\eta T_{n} \text {. }
$$

Based on the obtained in the [3] for the calculation formulas of the constraints it may be affirmed that loss of data set on switching node does not affect the accuracy of the transferred data inasmuch as such data sets are retransferred. Thus, possible denial of service on the switching nodes changes the time characteristics of the data transfer process.

The timing based on the obtained in [3] for the calculation formulas of the constraints and analyse the effect of possible losses at switching nodes of the data transfer should be analysed.

According to the nature of distribution, there are two types of errors [4]: uncorrelated, correlated.

Error model. It is known that errors in real computer networks $(\mathrm{CN})$ can arise in groups (data sets). Therefore, the evaluation of the pulse-frequency characteristic on the basis of uncorrelated errors can be used for approximate calculations, since it has an approximate character [5].

For a channel with uncorrelated errors, the simplest error model (the Poisson model) is often used. Its properties of computer networks as a source of error are given probability of error in the unit cell codeword $P_{n}$. In this case, all errors are considered to be independent. Let the probability of distortion of a single data element in $\mathrm{CN}$ is. Then the probability of a correct combination with $n$ elements:

$$
P_{p r}=\left(1-P_{p r}\right)^{n}
$$

If the properties of error-correcting code applied unknown proportion not found error depends on the 
number of parity bits $\mathrm{r}$ [9]. The probability of not detecting an error is defined as:

$$
P_{n o}=\left(1-\left(1-P_{p r}\right)^{n}\right) \cdot 2^{-r} \text {. }
$$

Analysis of time characteristics. Based on the calculation formulas obtained in [7] for the accepted restrictions, it can be asserted that the loss of packets on the switching nodes does not affect the reliability of the transmitted data, since such packets are retransmitted. Thus, possible failures in the service at the switching node change the time characteristics of the data transfer process.

The time characteristics based on the calculation formulas obtained in [4] for the adopted constraints and the effect of possible losses on the switching nodes on the data transfer process should be analysed:

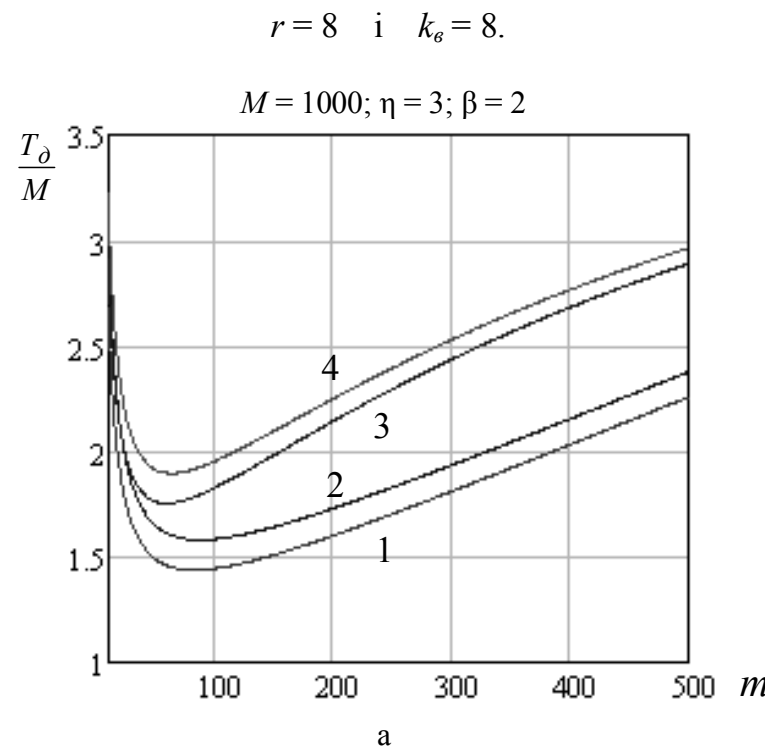

Fig. 1 shows that the relative mean time to deliver messages increases with the length of a package as in any $\mathrm{CN}$. Moreover, all of the curves have a distinct minimum. This is due to the fact that for relatively small packet lengths, there is a large redundancy due to overhead and test bits. With a further increase in the length of the packets the redundancy caused by retransfers increases [10].

Increased probability of switching nodes in loss leads to an increase of the relative mean time of message delivery for a wide range of data set lengths.

The relative average message delivery time increases with the degradation of the quality of the $\mathrm{CN}$ (Fig. 2).

Increased probability of switching nodes loss also leads to the relative increase of the average time of message delivery for all values of the distortion probability of the unit element in a $\mathrm{CN}[8]$.

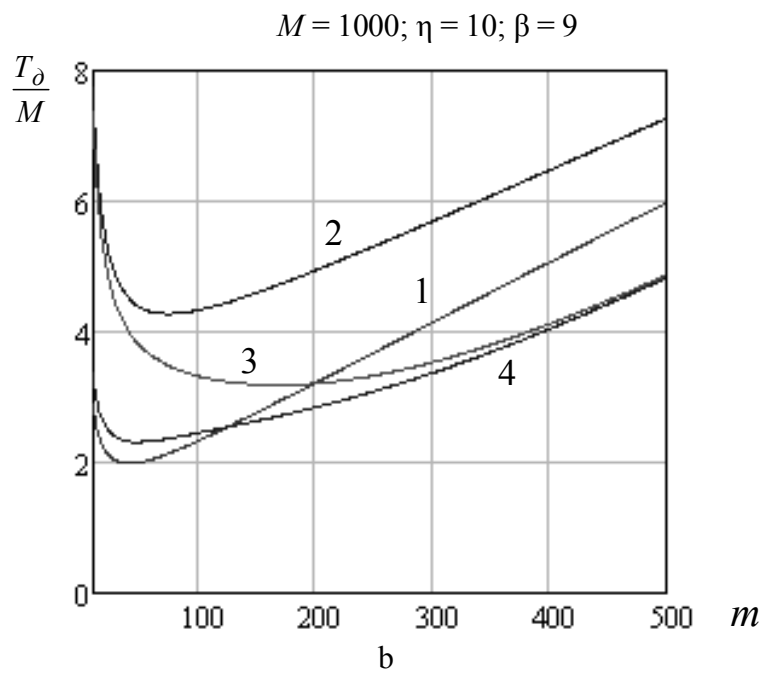

Fig. 1. Dependence of the relative average message delivery time on the data set length for: $1-P_{n}=10^{-4}, \mathrm{P}_{\text {втр }}^{\mathrm{BK}}=0 ; 2-\mathrm{P}_{\text {п }}=10^{-4}, \mathrm{P}_{\text {втр }}^{\text {ВК }}=10^{-2} ; 3-\mathrm{P}_{\Pi}=10^{-3}, \mathrm{P}_{\text {втр }}^{\text {ВК }}=0 ; 4-\mathrm{P}_{\text {п }}=10^{-3}, \mathrm{P}_{\text {втр }}^{\text {ВК }}=10^{-2}$
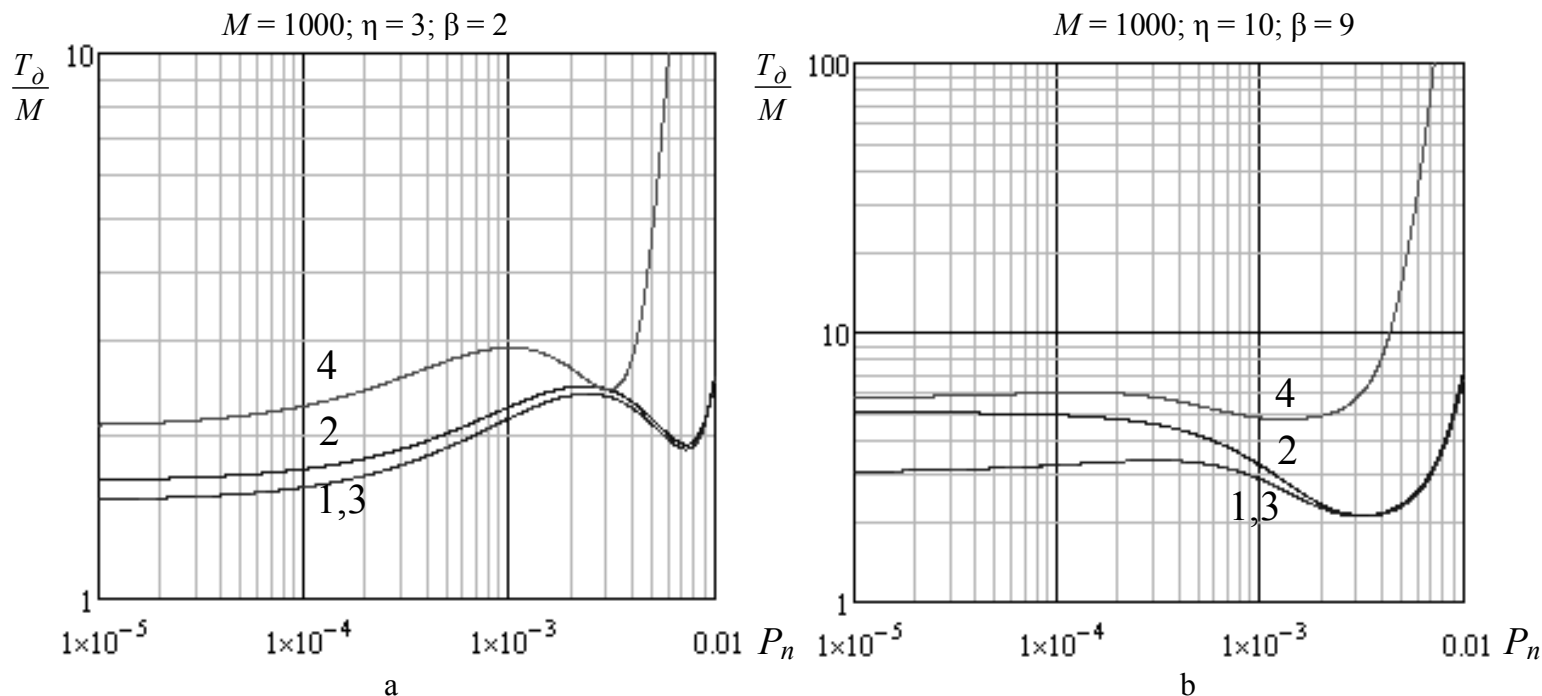

Fig. 2. Dependence of the relative average time of delivery of messages on the probability of distortion of a single element in a computer network when: $1-m=200, P_{\text {вmp }}^{B K}=0 ; 2-m=200, P_{\text {вmp }}^{B K}=10^{-2} ; 3-m=200, P_{\text {вmp }}^{B K}=10^{-5} ; 4-m=500, P_{\text {вmp }}^{B K}=0$ 
The increase in the probability of packet loss at switching nodes leads to an earlier increase in the relative average time of message delivery with a greater number of switching nodes along the route of the packet (Fig. 3).

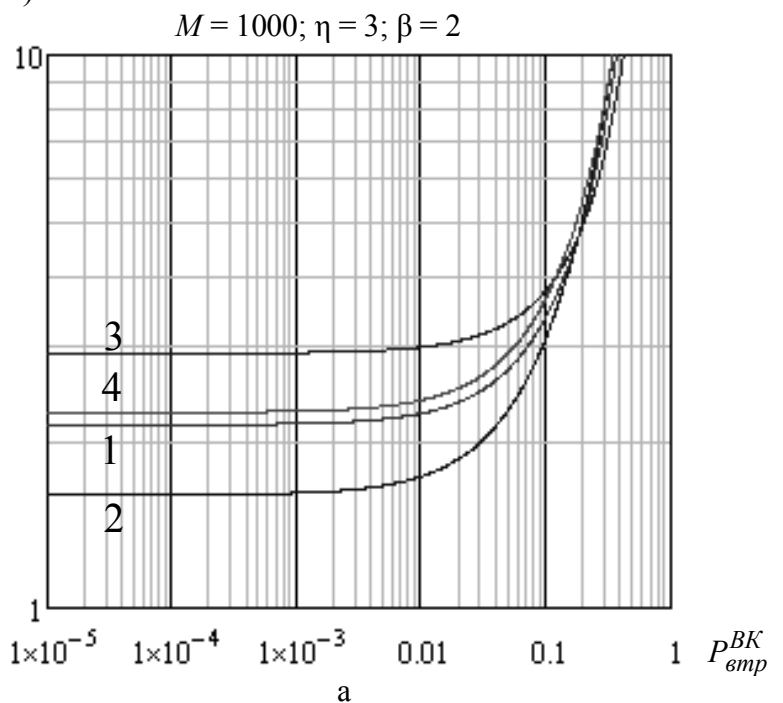

This statement more evident from the graph, the relative ratio of the average time of delivery if there is loss at the switching nodes relative to the average delivery time without loss of switching nodes (Fig. 4).

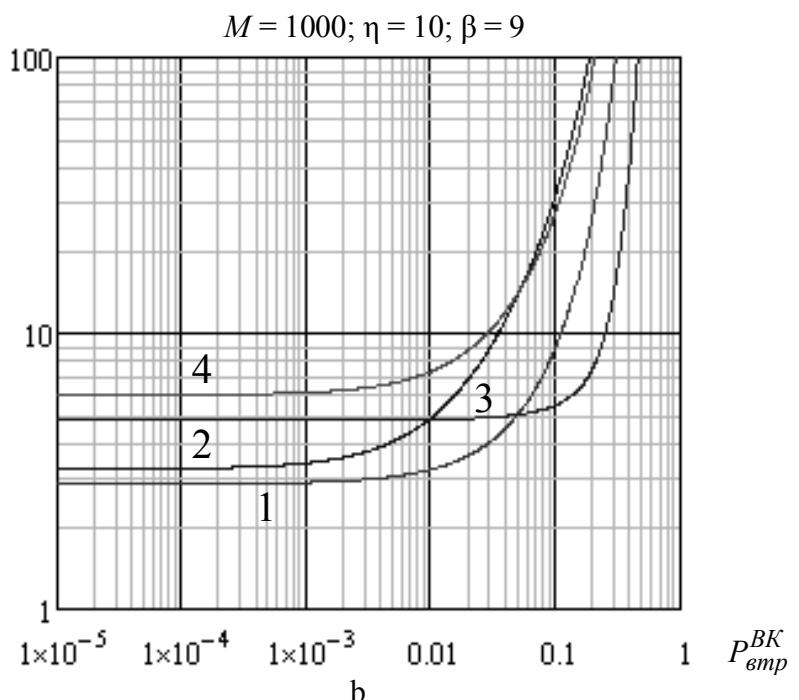

Fig. 3. Dependence of the relative average time of delivery of messages on the probability of data set loss on the switching nodes with: $1-m=200, P_{n}=10^{-3} ; 2-m=200, P_{n}=10^{-4} ; 3-m=500, P_{n}=10^{-3} ; 4-m=500, P_{n}=10^{-4}$
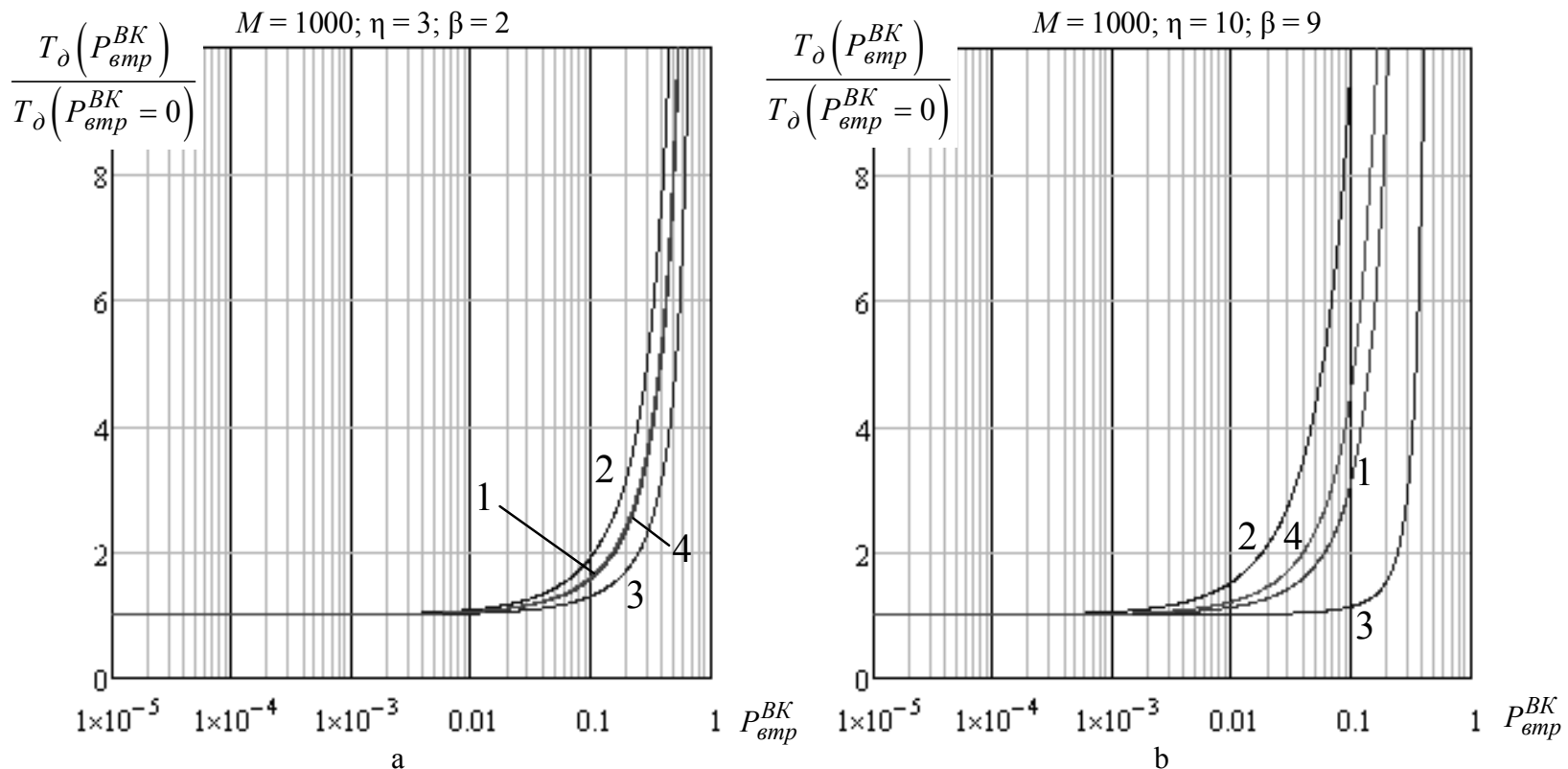

Fig. 4. Dependence of the ratio of the relative average message delivery time, taking into account the losses at the switching nodes to the relative average time of message delivery in the absence of losses at the switching nodes from the probability of packet loss at the switching nodes with: $1-m=200, P_{n}=10^{-3} ; 2-m=200, P_{n}=10^{-4} ; 3-m=500, P_{n}=10^{-3} ; 4-m=500, P_{n}=10^{-4}$

In addition, a significant increase in the probability of service failures at intermediate switching nodes leads to a sharp increase in the relative average packet delivery time [6].

\section{Conclusion}

The analysis of discard probability impact at interconnection switching nodes on temporary characteristics of data transfer process suggests that the increase of this probability leads to the increase of average time of massage delivery for a wide parameters range. Moreover, the impact of data sets loss at switching nodes is inherent for networks with a large number of retransmitting nodes. Special attention should be paid to the fact that even using high quality data lines (with small values of error probability of single element) the loss of data sets at switching nods can lead to complete termination of information exchange. 
REFERENCES

1. Oberemok, S.O. (2018), "Model obrobky paketiv v komutatsiynykh vuzlakh z povnozvyaznoyu topolohiyeyu merezhi ASU povitryanym rukhom", Systems of control, navigation and communication, PNTU, Poltava, Issue 1 (47), pp. 28-31.

2. Alekseyev, S.V. (2010), "Matematicheskaya model' protsessa peredachi dannykh cherez promezhutochnyye tsentry kommutatsii soobshcheniy dlya sluchaya primeneniya pomekhoustoychivogo koda $\mathrm{v}$ rezhime obnaruzheniya oshibok $\mathrm{s}$ proverkoy paketov poluchatelem", Zbirnik naukovikh prats' KhUPS, KhUPS, Kharkiv, Issue 3 (25), pp. 123-125.

3. Oberemok, S.O. (2018), "Matematychna model protsesu peredachi danykh v rezhymi vyyavlennya pomylok otrymuvachem z urakhuvannyam vidmov na vuzlakh komutatsiyi v merezhakh ASU povitryanym rukhom", Zbirnyk naukovykh prats NUOU, NUOU, Kyiv, Issue 4(31), pp. 78-83.

4. Shvartsman V.O. (2006), "Kachestvo uslug setey sleduyushchego pokoleniya”, Elektrosvyaz, No. 3, pp. 26-31.

5. Olifer, V. and Olifer, N. (2001), "Iskusstvo optimizatsii trafika", LAN, No.12, pp. 38-47.

6. Nazarov, A.N. (2002), Modeli i metody raschota strukturno-setevykh parametrov setey ATM, Goryachaya liniya - Telekom, Moscow, $256 \mathrm{p}$.

7. Zitzler, E. (2012), "Evolutionary Multiobjective Optimization”, Handbook of Natural Computing, Springer-Verlag Berlin Heidelberg, pp. 871-904.

8. Keller, J., Liu, D. and Foge D. (2016), Fundamentals of Computational Intelligence: Neural Networks, Fuzzy Systems, and Evolutionary Computation, Hoboken, John Wiley \& Sons Inc., NJ, 378 p.

9. Cencini, M., Cecconi, F. and Vulpiani A. (2010), Chaos: From Simple Models to Complex Systems, Hackensack, World Scientific, NJ, $460 \mathrm{p}$.

10. Walia, P. and Mehta, A. (2015), "Energy efficient geographic adaptive fidelity in wireless sensor networks", IOSR Journal of Computer Engineering, Vol. 17, Issue 5, Ver. 1, pp. 46-55, doi: 10.9790/0661-17514655.

Надійшла (received) 13.02.2018

Прийнята до друку (accepted for publication) 11.04.2018

\section{Оцінка впливу відмов обробки пакетів на часові характеристики процесу обробки даних в мережах АСУ повітряним рухом}

С. О. Оберемок, Ю. С. Довгий, С. І. Хмелевський, С. О. Рудь

При передачі інформації в мережах автоматизованих систем управління повітряним рухом висока ймовірність виникнення довготривалих пікових навантажень. Метою $є$ проведення аналізу впливу можливих відмов на вузлах комутації на основні часові характеристики процесу передачі даних в режимі виявлення помилок одержувачем. Показано, що збільшення ймовірності втрати пакетів на проміжних вузлах комутації призводить до зростання відносного середнього часу доставки повідомлень для широкого діапазону параметрів та може призвести до повного припинення інформаційного обміну. Ймовірнісно-часові характеристики методів управління процесом передачі пакетів в мережах обміну даними вимагають врахування впливу проміжних вузлів комутації. $€$ необхідність розглядати як наявність декількох потоків даних від інших джерел, так і можливість виникнення відмов в обслуговуванні на кожному 3 вузлів комутації. Отримали наступні результати. При використанні високоякісних каналів зв'язку (з малими значеннями ймовірності спотворення одиничного елементу) втрати пакетів на вузлах комутації можуть привести до повного припинення інформаційного обміну. Висновки. Проведений аналіз впливу ймовірності втрати пакетів на проміжних вузлах комутації на тимчасові характеристики процесу передачі даних свідчить про те, що збільшення цієї ймовірності призводить до зростання відносного середнього часу доставки повідомлень для широкого діапазону параметрів.

Ключов і слов а: передача даних; вузол комутації; ймовірнісно-часові характеристики; АСУ повітряним рухом; пакет даних; тайм-аут; кореляція; виявлення помилок.

Оценка влияния отказов обработки пакетов на временные характеристики процесса обработки данных в сетях АСУ воздушным движением

С. А. Оберемок, Ю. С. Долгий, С. И. Хмелевский, С. А. Рудь

При передаче информации в сетях автоматизированных систем управления воздушным движением высокая вероятность возникновения долговременных пиковых нагрузок. Целью является проведение анализа влияния возможных отказов на узлах коммутации на основные временные характеристики процесса передачи данных в режиме обнаружения ошибок получателем. Показано, что увеличение вероятности потери пакетов на промежуточных узлах коммутации приводит к росту относительного среднего времени доставки сообщений для широкого диапазона параметров и может привести к полному прекращению информационного обмена. Вероятностно-временные характеристики методов управления процессом передачи пакетов в сетях обмена данными требуют учета влияния промежуточных узлов коммутации. Есть необходимость рассматривать как наличие нескольких потоков данных от других источников, так и возможность возникновения отказов в обслуживании на каждом из узлов коммутации. Получили следующие результаты. При использовании высококачественных каналов связи (с малыми значениями вероятности искажения единичного элемента) потери пакетов на узлах коммутации могут привести к полному прекращению информационного обмена. Выводы. Проведенный анализ влияния вероятности потери пакетов на промежуточных узлах коммутации на временные характеристики процесса передачи данных свидетельствует о том, что увеличение этой вероятности приводит к росту относительного среднего времени доставки сообщений для широкого диапазона параметров.

Ключевые слова: передача данных; узел коммутации; вероятностно-временные характеристики; АСУ воздушным движением; пакет данных; тайм-аут; корреляция; выявление ошибок. 